\title{
Red, white and blues: Darier disease and mood disorder
}

\author{
Andrew J Newman, Dustin Mullens, Mitch Manway, Jason Barr
}

Dermatology Residency, Affiliated Dermatology, Scottsdale, Arizona, USA

Correspondence to Dr Andrew J Newman, anewman@affderm.com, andrew.newman@tu.edu

Accepted 13 August 2018

D Check for updates

(c) BMJ Publishing Group Limited 2018. No commercial re-use. See rights and permissions. Published by BMJ.

To cite: Newman AJ, Mullens D, Manway M, et al. BMJ Case Rep Published Online First: [please include Day Month Year]. doi:10.1136/bcr-2018227004

\section{DESCRIPTION}

A middle-aged woman presented with a progressively worsening rash for 25 years. The rash was foul smelling and tender, occurring symmetrically in the folds of her abdomen and lower legs. Her medical history was significant for major depressive disorder. She had been receiving care from multiple psychiatrists over the last 10 years, and she has been hospitalised in inpatient psychiatric facilities for acute psychotic episodes. She admitted to having two of five siblings with similar skin problems, both additionally having been diagnosed with mood disorders including bipolar disorder and major depressive disorder. The patient stated the other three siblings were healthy. On examination, the patient had plaques of confluent papules and foulsmelling, weeping patches which were distributed over the folds of her chest and abdomen, as well as the flexure surfaces of her bilateral lower extremities (figure 1). Examination of her nails revealed red and white longitudinal striations and v-shaped nicking (figure 2). Two punch biopsies were performed in the involved skin which demonstrated acantholytic dyskeratoses. The patient was accordingly diagnosed with Darier disease (DD) and treated with appropriate wound care, topical corticosteroids and doxycycline with an intention to begin topical retinoids once the affected skin had epithelialised. The patient was also advised to continue following up regularly with her mental health specialists.

This patient and her family compellingly showcase a genetic inheritance of both mood disorder and skin disease in DD. In a previous study, 100 unrelated individuals with DD were assessed for using standardised neuropsychiatric measures and the findings concluded that neuropsychiatric symptoms in DD are not simply a psychological reaction to having a skin disease but are consistent with the pleiotropy hypothesis that mutations in the

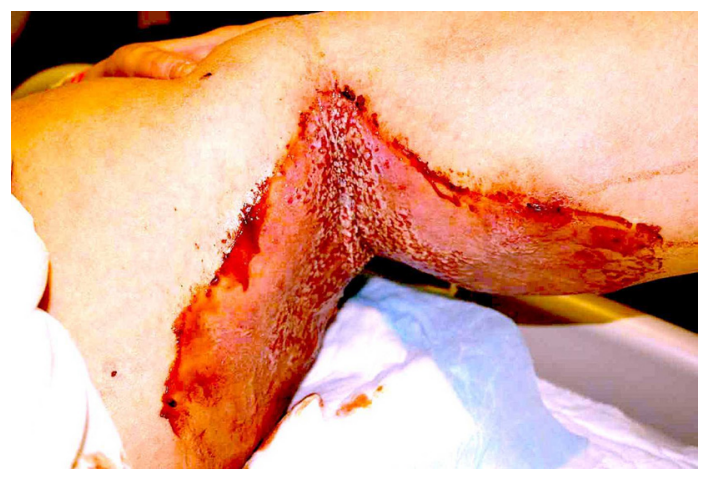

Figure 1 Popliteal fossa of left lower extremity showing a severely denuded and weeping patch.

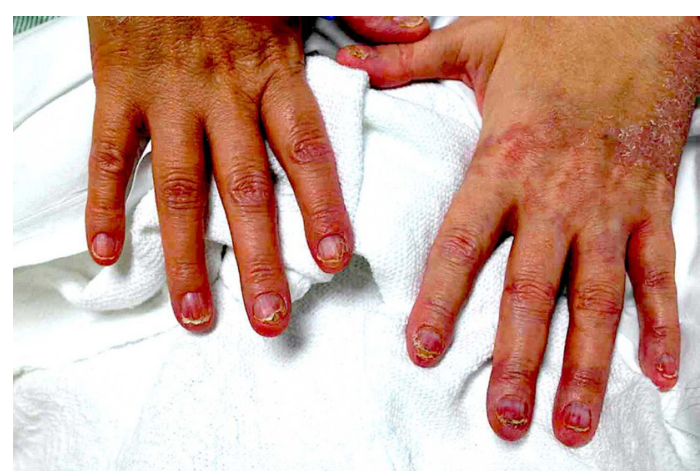

Figure 2 Fingernails demonstrating red and white longitudinal striations with v-shaped nicking.

ATP2A2 gene, in addition to causing DD, confer susceptibility to neuropsychiatric features. ${ }^{1}$ It is critical for clinicians to understand these ATP2A2 genotype-phenotypes in order to appropriately address both the neuropsychiatric and cutaneous diseases in patients with DD.

\section{Learning points}

- Individuals with Darier disease (DD) often have both neuropsychiatric disease and skin disease.

- The co-occurrence of neuropsychiatric disease and skin disease in individuals with DD is likely due to pleiotropy.

- Appreciation for the variety of ATP2A2 genotype-phenotypes that exist in DD may help clinicians to address both the neuropsychiatric and cutaneous diseases in patients with DD.

Acknowledgements The authors acknowledge the staff and faculty of Honor Health Medical Center and Affiliated Dermatology in Scottsdale, Arizona, for their support.

Contributors AJN formed the text related to the patient presentation and edited the discussion section. DM provided valuable literature review and contributed to the discussion section text. MM edited the manuscript in its entirety. JB is an overseeing medical consultant, providing dermatologic detail to maintain the accuracy of the medical text.

Funding The authors have not declared a specific grant for this research from any funding agency in the public, commercial or not-for-profit sectors.

Competing interests None declared.

Patient consent Obtained.

Provenance and peer review Not commissioned; externally peer reviewed.

\section{REFERENCE}

1 Gordon-Smith K, Jones LA, Burge SM, et al. The neuropsychiatric phenotype in Darier disease. Br J Dermatol 2010;163:515-22. 
Copyright 2018 BMJ Publishing Group. All rights reserved. For permission to reuse any of this content visit http://group.bmj.com/group/rights-licensing/permissions.

BMJ Case Report Fellows may re-use this article for personal use and teaching without any further permission.

Become a Fellow of BMJ Case Reports today and you can:

- Submit as many cases as you like

- Enjoy fast sympathetic peer review and rapid publication of accepted articles

Access all the published articles

- Re-use any of the published material for personal use and teaching without further permission

For information on Institutional Fellowships contact consortiasales@bmjgroup.com

Visit casereports.bmj.com for more articles like this and to become a Fellow 